\title{
Response of the goat mammary gland to infection with Staphylococcus aureus revealed by gene expression profiling in milk somatic and white blood cells
}

\author{
Paola Cremonesi ${ }^{1 \dagger}$, Rossana Capoferri ${ }^{2^{*}}{ }^{\prime}$, Giuliano Pisoni ${ }^{3}$, Marcello Del Corvo ${ }^{4}$, Francesco Strozzi ${ }^{4}$, Rachel Rupp ${ }^{5}$, \\ Hugues Caillat ${ }^{5}$, Paola Modesto ${ }^{3,6}$, Paolo Moroni ${ }^{3,7}$, John L Williams ${ }^{4}$, Bianca Castiglioni ${ }^{1}$ and Alessandra Stella $a^{1,4}$
}

\begin{abstract}
Background: S. aureus is one of the main pathogens responsible for the intra-mammary infection in dairy ruminants. Although much work has been carried out to understand the complex physiological and cellular events that occur in the mammary gland in response to $S$. aureus, the protective mechanisms are still poorly understood. The objectives of the present study were to investigate gene expression during the early response of the goat mammary gland to an experimental challenge with S. aureus, in order to better understand the local and systemic response and to compare them in two divergent lines of goat selected for high and low milk somatic cell scores.

Results: No differences in gene expression were found between high and low SCS (Somatic Cells Score) selection lines. Analysing the two groups together, an expression of 300 genes were found to change from T0 before infection, and T4 at 24 hours and T5 at 30 hours following challenge. In blood derived white blood cells 8 genes showed increased expression between T0 and T5 and 1 gene has reduced expression. The genes showing the greatest increase in expression following challenge (5.65 to 3.16 fold change) play an important role in (i) immune and inflammatory response (NFKB1, TNFAIP6, BASP1, IRF1, PLEK, BATF3); (ii) the regulation of innate resistance to pathogens (PTX3); and (iii) the regulation of cell metabolism (CYTH4, SLC2A6, ARG2). The genes with reduced expression ( -1.5 to -2.5 fold) included genes involved in (i) lipid metabolism (ABCG2, FASN), (ii) chemokine, cytokine and intracellular signalling (SPPl), and (iii) cell cytoskeleton and extracellular matrix (KRT19).

Conclusions: Analysis of genes with differential expression following infection showed an inverse relationship between immune response and lipid metabolism in the early response of the mammary gland to the $S$. aureus challenge. PTX3 showed a large change in expression in both milk and blood, and is therefore a candidate for further studies on immune response associated with mastitis.
\end{abstract}

\section{Background}

Mastitis is an inflammation of the mammary gland to infection, and is usually caused by bacteria. Mastitis represents one of the most economically important health traits for milk production, which makes it among the major concerns for the livestock sector [1]. Although much work has been carried out in dairy ruminants to

\footnotetext{
* Correspondence: rossana.capoferri@istitutospallanzani.it

${ }^{\dagger}$ Equal contributors

"IDRA-LAB Istituto Sperimentale Italiano "L. Spallanzani", via Einstein, Lodi 26900, Italy

Full list of author information is available at the end of the article
}

understand the complex physiological and cellular events that occur in the mammary gland in response to pathogens [2-4], the protective mechanisms are still poorly understood. Invading pathogens activate the immune defence in the udder, which is a complex biological process involving not only resident and recruited immune cells, but also mammary epithelial and endothelial cells. The result is an increase in the number of somatic cells in milk. Polymorphic nuclear neutrophil granulocytes are the predominant cell type recruited to the gland [5,6], and their numbers increase 10- to 50fold during the first few hours following infection $[7,8]$.

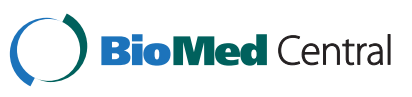


The aetiology of the pathogens influences the severity of the symptoms: contagious pathogens, such as Staphylococcus aureus or Streptococcus agalactiae, cause ongoing chronic disease and sub-clinical mastitis, while the environmental coliform bacteria often cause acute, clinical mastitis [9]. Variation in presentation of the disease between pathogens may be the result of differences in the capability of the innate immune system to mount initial defences. This may be linked to factors such as recognition of pathogen derived antigen e.g. by Toll-like receptors (TLR) or the mobilisation of bactericidal effector molecules such as the $\beta$-defensins.

Immediate and appropriate recognition of the invading pathogen is fundamental for the prompt and proper activation of the immune response of the host. Infection will only be able to develop and the disease become manifest if these mechanisms fail. Studies in humans and model organisms have revealed that receptors and effector molecules of the innate immune system are a crucial first line of disease defence. An infection sets in motion a, normally, well ordered cascade of defence mechanisms to eliminate the pathogen, in which innate and adaptive immune mechanisms cooperate. However, there are no consistent descriptions of mastitis-related mammary gland-specific expression of the key factors controlling the innate immune system. Previous analyses have been focused on effector mechanisms in later stages of the adaptive immune response to an infection [10], studies of the early phases of infection which could shed light on innate defence mechanisms process in the udder are currently missing. Such studies can only be achieved in controlled infection experiments where the time of infection and pathogen involved are known.

Disease response is a complex trait under multi-genic control, which makes it difficult to develop appropriate genetic selection strategies for improved immune response. Nevertheless, a genetic component of host responses to bacteria during intra-mammary infections has been widely documented, and mastitis has a heritability up to $20 \%$ in goats $[11,12]$. Breeding to improve resistance to mastitis has had limited success, as very little is known about the genetic basis of resistance and functional complexity of the host pathogen interaction during infection. The overriding problems of developing an appropriate selection strategy to control mastitis are (i) the plethora of pathogens that cause mastitis, each of which may elicit a different immune response, and (ii) the strong environmental and management effects on the incidence of mastitis [13]. The number of somatic cells in milk is correlated with intra-mammary infection and cattle breeders have used somatic cell scores (SCS) in genetic selection for reducing mastitis. However, it is not certain how well SCS predicts immune response to infection with a mastitis causing pathogens, or incidence of clinical mastitis. Nevertheless, breeding programmes for mastitis resistance in dairy cattle $[14,15]$ and sheep [16] have used SCS as a selection criterion. For goats, the relevance of SCS as a predictor of parameters of udder health and the susceptibility against mastitis is still untested.

Over the last decade techniques for studying the transcriptome have improved dramatically, in particular the use of microarrays that represent a large proportion of the expressed genes. The application of these approaches for dairy ruminants transcriptome profiling has identified genes, pathways and regulatory networks activated in mammary tissues during experimental infection by various pathogens, including $E$. coli, $S$. aureus and $S$. uberis [10,17-21]. The meta-analysis of transcriptionprofiling data from six independent studies of the mammary gland infected with different pathogens identified common signatures of infection among species and that were characteristic of early vs late stage responses [22].

The objectives of the present study were to investigate the early response of goats to a controlled infection with $S$. aureus by following gene expression responses in immune related cells in the blood and milk in order to better understand the local and systemic response. The study also compared the responses of two divergent lines of goat selected for high and low milk SCS.

\section{Results}

Intra-mammary S. aureus growth following experimental infection

Following intra-mammary experimental infection with $S$. aureus, the pathogen could be cultured from the milk of all 10 experimentally infected animals at 6 hours, and at the final sampling $30 \mathrm{~h}$ post-infection, S. aureus could be cultured from 9 of the 10 infected animals. S. aureus present in milk samples reached a maximum at $18 \mathrm{~h}$ post-infection with a mean of $5.8 \log 10 \mathrm{CFU} / \mathrm{ml}$ (Colony Forming Unit/ml) in the Low SCS (LSCS) line animals and $6.1 \log 10 \mathrm{CFU} / \mathrm{ml}$ the High SCS (HSCS) selection line goats. The number of $S$. aureus then remained constant for the rest of the study period (Figure 1). Strain analysis using the RAPD-PCR (Randomly Amplified Polymorphic DNA-PCR) method confirmed that $S$. aureus isolated from infected udders were the same as the strain used for the infection (data not shown). The control PBS-infused udders remained free from detectable infection throughout the study. No significant difference was observed in $S$. aureus counts at different time points in milk from LSCS and HSCS goats.

\section{Systemic and localized inflammatory responses to S. aureus intra-mammary infection}

As an indicator of a systemic response to $S$. aureus infection, rectal temperatures were monitored throughout 


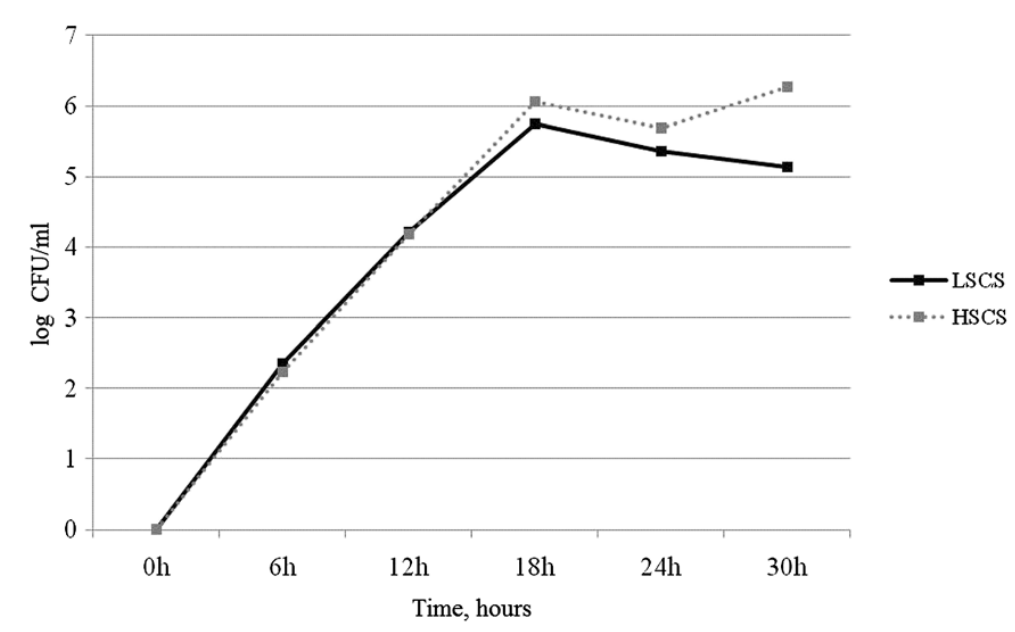

Figure 1 S. aureus counts in milk from LSCS (Low Somatic Cell Score) and HSCS (High Somatic Cell Score) goats at different time points. Mean S. aureus $\log 10 \mathrm{CFU} / \mathrm{ml}$ in milk was measured in LSCS and HSCS goats at 0, 6, 12, 18, 24 and 30 hours post infection. S. aureus counts peaked at $18 \mathrm{~h}$ post-challenge with means of $5.8 \log 10 \mathrm{CFU} / \mathrm{ml}$ in LSCS line animals and $6.1 \log 10 \mathrm{CFU} / \mathrm{ml} \mathrm{HSCS} \mathrm{selection}$ line goats. From $18 \mathrm{~h}$ to $30 \mathrm{~h}$ this value remained constant (paired t-test).

the study. Body temperature showed an upward trend from 0 to $18 \mathrm{~h}$ post-infection, however, the increased temperature was only significant $(\mathrm{p}=0.05)$ at the 24 and $30 \mathrm{~h}$ time points. Temperatures reached a maximum $30 \mathrm{~h}$ after infection and reached a peak mean $( \pm$ S.D.) of 40.2 $( \pm 0.5)$ and $40.7( \pm 0.6){ }^{\circ} \mathrm{C}$ in LSCS and HSCS goats, respectively, which is not a significant difference (Figure 2).

The systemic response to intra-mammary infection with $S$. aureus was characterized by a significant decrease $(\mathrm{p}=0.05)$ of total blood leukocyte (TBL) and of neutrophil (NEU) numbers $18 \mathrm{~h}$ post-infection. The TBL and NEU counts were 13.7 and $6.0 \times 10^{3} \mathrm{cells} / \mathrm{ml}$ in LSCS goats and 11.5 and $4.0 \times 10^{3}$ cells $/ \mathrm{ml}$ in HSCS goats. The lowest blood cell counts were reached at $30 \mathrm{~h}$ post-infection, when the TBL and NEU counts were 9.8 and $4.2 \times 10^{3}$ and 5.6 and $2.0 \times 10^{3}$ cells $/ \mathrm{ml}$ in LSCS and HSCS goats, respectively (Figure 3 ).

Changes in milk SCC (Somatic Cell Count) were monitored as an indicator of local response. Mean milk SCCs $\left(\mathrm{x} 10^{3} / \mathrm{ml}\right)$, before $S$. aureus intra-mammary infection, were $6.0 \times 10^{5}$ and $4.5 \times 10^{5}$ for LSCS left and right udder halves respectively, and $8.8 \times 10^{5}$ and $5.2 \times 10^{5}$ for HSCS left and right udder halves respectively at $\mathrm{T} 5$. Increases in milk SCC were initially observed after $18 \mathrm{~h}$ of infection. Milk SCC in the right hand control udders, infused with saline, remained unchanged throughout the study in

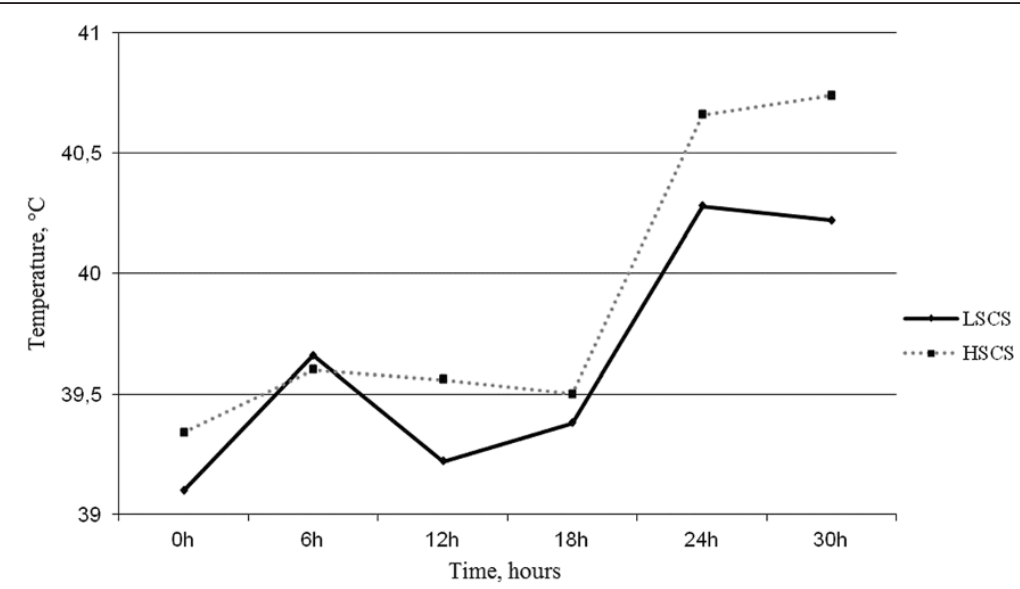

Figure 2 Mean body temperature of LSCS (Low Somatic Cell Score) and HSCS (High Somatic Cell Score) goats. Rectal temperature was monitored throughout the study. A temperature increase was only significant (paired t-test, $p=0.05$ ) at the 24 and $30 \mathrm{~h}$ time points and reached a maximum $30 \mathrm{~h}$ after infection. A paired t-test was applied to milk SCC of right udders in LSCS and HSCS goats to test if the changes at each time point were significant. No significant difference was observed in mean body temperature of LSCS and HSCS goats at different time points. 


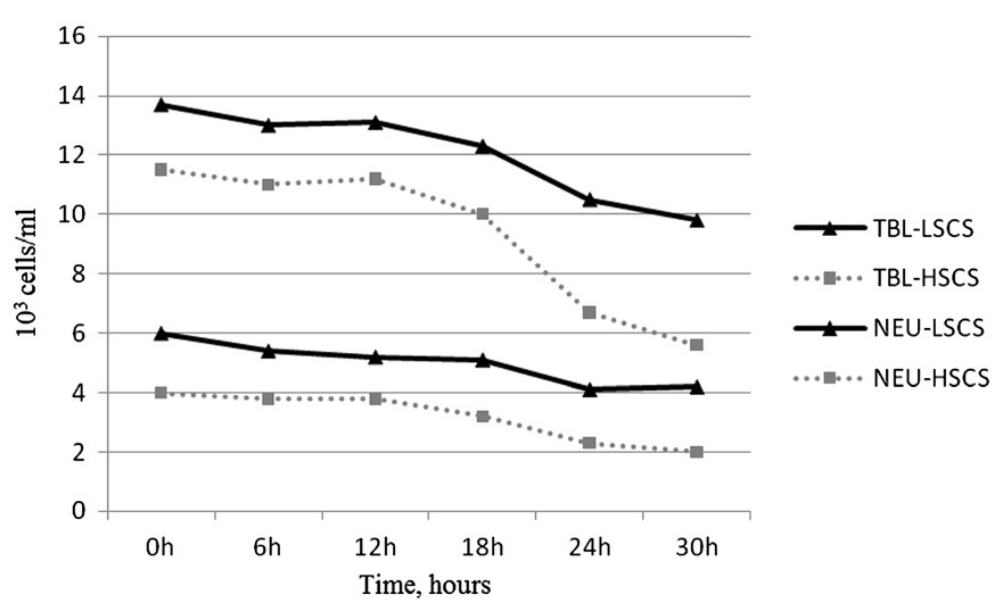

Figure 3 Total blood leukocyte (TBL) and of neutrophils (NEU) counts of LSCS (Low Somatic Cell Score) and HSCS (High Somatic Cell Score) goats. $18 \mathrm{~h}$ after challenge the TBL and NEU counts were 13,7 and $6 \times 10^{3} \mathrm{cells} / \mathrm{ml}$ in LSCS goats and 11,5 and $4 \times 10^{3}$ cells $/ \mathrm{ml}$ in HSCS goats, respectively. The lowest counts were reached at 30h post-infection (paired t-test).

LSCS goats, while milk SCC in right hand udder halves of HSCS goats increased significantly $(\mathrm{p}=0.05)$ (Figure 4$)$.

The differential milk somatic cell composition was compared between LSCS and HSCS goats before and following infection. The mean proportion of macrophages in LSCS (19.98\%) and HSCS (11.39\%) prior to challenge was statistically significant $(\mathrm{p}=0.030$; Table 1$)$. After the challenge, for LSCS a significant increase in neutrophils was observed at T4 vs T0 $(\mathrm{p}=0.0031)$ and T5 vs T0 ( $\mathrm{p}=0.0010)$ and decrease was observed for macrophages ( $\mathrm{T} 4$ vs $\mathrm{T} 0, \mathrm{p}=0.0085$; $\mathrm{T} 5$ vs $\mathrm{T} 0 \mathrm{p}=0.0009$ ), lymphocytes ( $\mathrm{T} 4$ vs $\mathrm{T} 0, \mathrm{p}=0.014$; $\mathrm{T} 5$ vs $\mathrm{T} 0, \mathrm{p}=0.016$ ) and epithelial cells ( $\mathrm{T} 4$ vs $\mathrm{T} 0, \mathrm{p}=0.014$; $\mathrm{T} 5$ vs $\mathrm{T} 0, \mathrm{p}=0.049$ ) (Additional file 1). For HSCS a significant increase in neutrophils was found at T5 vs T0 $(\mathrm{p}=0.028)$, while significant decreases were seen for macrophages (T4 vs T0, $\mathrm{p}=0.016$; $\mathrm{T} 5$ vs $\mathrm{T} 0, \mathrm{p}=0.010$ ) and for epithelial cells ( $\mathrm{T} 5$ vs $\mathrm{T} 0, \mathrm{p}=0.027$ ).

Therefore, statistically different increase and variations in somatic cell composition were seen in the in right hand udder halves of HSCS vs LSCS goats (Figure 4 and Table 1), whereas there were no statistically significant differences in either blood or milk between the HSCS and LSCS goats for the other phenotypic responses (i.e. rectal temperature, milk SCC, TBL, NEU) at any of the time points after infection.

\section{Gene expression analysis of milk samples}

No differences in gene expression were found at any of the time points between the two selection lines

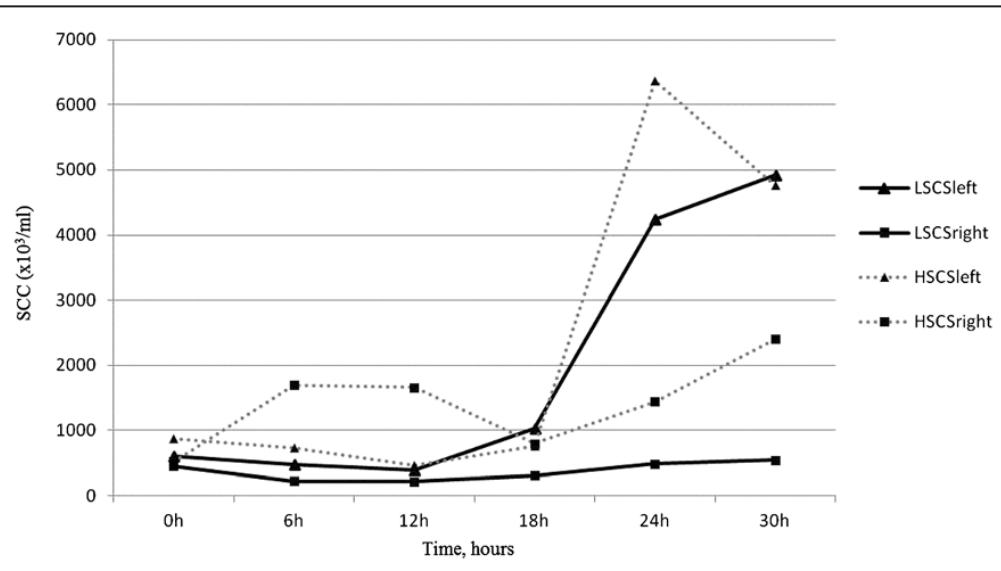

Figure 4 Somatic cell count of LSCS (Low Somatic Cell Score) and HSCS (High Somatic Cell Score) goats in right and left udders. Mean milk SCC $\left(\times 10^{3} / \mathrm{ml}\right)$ of LSCS and HSCS goats in left udders (S. aureus-infected) and in right udders (PBS-infused) was measured at 0, 6, 12, 18,24 and 30 hours post infection. Increases in milk SCC were initially observed after $18 \mathrm{~h}$ of infection. Milk SCC in the right hand control udders remained unchanged throughout the study in LSCS goats, while milk SCC in left hand udder halves of HSCS goats increased twofold (paired t-test, $p=0.05$ ). 
Table 1 Differential cell counts (DCCs) in milk somatic cells in LSCS and HSCS animals during five time points postinfection. Mean and Standard Deviation (Dev. St) of the percentages of polymorfonuclear (PMN), macrophages (M), lymphocytes (L) and epithelial cells (E) at all time points are indicated

\begin{tabular}{|c|c|c|c|c|c|c|c|c|c|c|c|c|c|}
\hline & & Mean T0 & Dev. St & Mean T1 & Dev. St & Mean T2 & Dev. St & Mean T3 & Dev. St & Mean T4 & Dev. St & Mean T5 & Dev. St \\
\hline \multirow[t]{4}{*}{$\mathrm{LSCS}$} & PMN & 52.43 & 11.16 & 55.14 & 10.70 & 58.26 & 12.72 & $65.80^{* *}$ & 10.05 & $83.55^{* * *}$ & 4.99 & $85.21^{* * *}$ & 7.78 \\
\hline & $M$ & 19.98 & 6.34 & 12.89 & 2.92 & 14.57 & 8.32 & $10.88^{* *}$ & 4.93 & $4.76^{* * *}$ & 3.08 & $4.41^{* * *}$ & 4.92 \\
\hline & $\mathrm{L}$ & 8.26 & 4.37 & 10.35 & 5.73 & 9.11 & 5.32 & 5.35 & 2.46 & $1.49^{* *}$ & 1.07 & $0.20^{* *}$ & 0.45 \\
\hline & $E$ & 19.32 & 3.47 & 21.62 & 9.53 & 18.06 & 7.58 & 17.98 & 7.20 & $10.20^{* *}$ & 3.68 & $10.18^{* *}$ & 4.68 \\
\hline \multirow[t]{4}{*}{$\mathrm{HSCS}$} & PMN & 56.26 & 17.11 & 58.41 & 12.09 & 55.05 & 8.57 & 69.33 & 19.46 & 82.64 & 8.36 & $84.50^{* *}$ & 8.58 \\
\hline & $M$ & 11.39 & 2.02 & 11.72 & 2.55 & $8.62^{* *}$ & 2.84 & $5.30^{* *}$ & 2.73 & $4.09^{* *}$ & 2.58 & $4.61^{* *}$ & 2.83 \\
\hline & $\mathrm{L}$ & 9.15 & 9.24 & 9.80 & 4.16 & 7.78 & 7.83 & 1.97 & 2.08 & 0.91 & 1.55 & 0.55 & 0.80 \\
\hline & $E$ & 23.21 & 8.42 & 20.07 & 7.02 & 28.55 & 9.20 & 23.41 & 20.12 & 12.36 & 6.83 & $10.35^{* *}$ & 6.33 \\
\hline
\end{tabular}

${ }^{* *}$ p-value $<0.05 ;{ }^{* * *}$-value $<0.01$.

(HSCS vs LSCS). Analysing the two groups together (HSCS + LSCS), a total of 300 genes were found to be differentially expressed ( $\mathrm{p}$ value $<0.01$ and $\log 2$ fold change > 1.5) in milk SCC between T0 and T4 and 128 genes between T0 and T5. Among these genes, the majority (251 for T4 vs T0 and 123 for T5 vs T0) showed an increase in expression. Ingenuity Pathway Analysis (IPA; Ingenuity Systems, Inc.), was able to identify 259 and 127 genes respectively for T4 and T5 of milk samples, based on comparative annotation using human or mouse orthologs within the IPA Knowledge base (Additional files 2 and Additional file 3). The 10 genes in milk somatic cells (MSC) showing the greatest increase in expression post infection between 5.6 and 3.2 fold (Table 2) play an important role in (i) immune and inflammatory response (NFKB1, TNFAIP6, BASP1, IRF1, $P L E K, B A T F 3)$; (ii) the regulation of innate resistance to pathogens (PTX3); and (iii) the regulation of cell metabolism (CYTH4, SLC2A6, ARG2). Fewer genes showing reduced expression between -1.5 to -2.5 fold (Table 3 ) were involved in (i) lipid metabolism (ABCG2, FASN), (ii) chemokine, cytokine and intracellular signalling (SPPI), and (iii) the cytoskeleton and extracellular matrix (KRT19).

\section{Canonical pathway}

The most represented canonical signalling and metabolic pathways among the differentially expressed genes at T4 and T5 included MIF-mediated Glucocorticoid Regulation, MIF Regulation of Innate Immunity, NF-kB Signalling, IL-10 Signalling and Hypoxia Signalling in Cardiovascular System for T4 and Production of Nitric Oxide and Reactive Oxygen Species in Macrophages, LXR/RXR Activation, Toll-like Receptor Signalling, Acute Phase Response Signalling and MIF-mediated Glucocorticoid Regulation for T5 (Table 4 and Additional file 4). The majority of genes with $>1.5$ fold change in expression between $\mathrm{T} 0$ and T5 within these pathways had an increase in expression. Among the five pathways, three were related to immune or inflammatory functions: IL-10 Signalling, which limits the inflammatory response, Production of Nitric Oxide and Reactive Oxygen Species in Macrophages and MIF-mediated Glucocorticoid regulation, which promote the inflammatory response. The pathway analysis also revealed that the Toll-like Receptor Signalling pathway was activated. Toll-like receptor activation is known to stimulate the synthesis of pro-inflammatory cytokines and chemokines in response to the bacterial infection, and the $L X R / R X R$ Activation pathway which is involved in inflammation and lipid metabolism.

At T4 and T5, 19 and 11 networks were identified using Ingenuity pathway analysis, respectively. The T4 networks contained a total of 244 differentially expressed genes which were involved in pathways and functions including the Cellular Movement, Haematological System, Immune Cell Trafficking, Haematopoiesis, Tissue Development, Antigen Presentation, Cellular Compromise, Cellular Function and Maintenance and Inflammatory Response. The T5 networks contained a total of 109 differentially expressed genes involved in pathways and functions including Inflammatory Response, Digestive System Development and Function, Hepatic System Development and Function, Cell-To-Cell Signalling and Interaction, Tissue Development, Haematological System Development and Function, Kidney Failure, Organismal Injury and Abnormalities, Renal and Urological Disease, Tumor Morphology, Amino Acid Metabolism, Small Molecule Biochemistry, Cell Death, Cellular Compromise.

\section{Meta-analysis}

The meta-analysis of expression data from the milk samples cells across all the time points identified twenty differentially expressed genes ( $p$ value <0.0001). These genes could be placed into 5 pathways, with 1 gene (NFKB1) in common. Two genes (TLR2 and NFKBIA) were common to 3 pathways: Toll like receptor signalling, role of pattern recognition receptors in recognition of bacteria and viruses, production of nitric oxide and 
Table 2 List of the top 10 genes with the greatest increase in expression post infection in milk somatic cells due to intra-mammary infection with S. aureus

Gene Gene name Primary functions fold

symbol

\section{T4}

PTX3 Pentraxin 3, long

PLEK Pleckstrin

$|R F|$

NCF1

SLC2A6

solute carrier family 2

(facilitated glucose transporter), member 6

BASP1 brain abundant, membrane attached signal protein 1

CYTH4 cytohesin 4

TNFAIP6 tumor necrosis factor, alpha-induced protein 6

COL3A1 collagen, type III, alpha 1

BATF3 basic leucine zipper transcription factor, ATF-like 3

T5

PTX3 Pentraxin 3, long

S100A9 S100 calcium binding protein A9

ICAM1 intercellular adhesion molecule 1

SOD2

superoxide dismutase 2, mitochondrial

PLEK Pleckstrin

S100A8 regulation of innate resistance to pathogens, inflammatory reactions, possibly clearance of self-components and female fertility

Major protein kinase C substrate of platelets

4.4

binds to the upstream regulatory region of type I IFN and IFN-inducible $\mathrm{MHC}$ class I genes (the interferon consensus sequence (ICS)) and activates those genes. Acts as a tumor suppressor

activation of the latent NADPH oxidase (necessary for superoxide production)

Facilitative glucose transporter; binds cytochalasin B with low affinity

encodes a membrane bound protein with several transient phosphorylation sites and PEST motifs

Promotes guanine-nucleotide exchange on ARF1 and ARF5. Promotes the activation of ARF through replacement of GDP with GTP

involved in cell-cell and cell-matrix interactions during inflammation and tumorigenesis

Collagen type III occurs in most soft connective tissues along with type I collagen

negative regulator of $\mathrm{AP}-1$-mediated transcription by heterodimerizing with JUN and binding DNA at 12-O-tetradecanoylphorbol-13-acetate response elements (TRE) (consensus: 5'-TGA[CG]TCA-3'). Represses IL2 and MMP1 promoter activities

regulation of innate resistance to pathogens, inflammatory reactions, possibly clearance of self-components and female fertility

Calcium-binding protein. Has antimicrobial activity towards bacteria and fungi. Important for resistance to invasion by pathogenic bacteria. Up-regulates transcription of genes that are under the control of NF-kappa-B. Plays a role in the development of endotoxic shock in response to bacterial lipopolysaccharide (LPS) (By similarity). Promotes tubulin polymerization when unphosphorylated. Promotes phagocyte migration and infiltration of granulocytes at sites of wounding. Plays a role as a pro-inflammatory mediator in acute and chronic inflammation and up-regulates the release of IL8 and cell-surface expression of ICAM1. Extracellular calprotectin binds to target cells and promotes apoptosis. Antimicrobial and proapoptotic activity is inhibited by zinc ions

During leukocyte trans-endothelial migration, ICAM1 engagement promotes the assembly of endothelial apical cups through ARHGEF26/ SGEF and RHOG activation. In case of rhinovirus infection acts as a cellular receptor for the virus

Destroys radicals which are normally produced within the cells and which are toxic to biological systems

Major protein kinase C substrate of platelets

Calcium-binding protein. Has antimicrobial activity towards bacteria and fungi. Important for resistance to invasion by pathogenic bacteria. Up-regulates transcription of genes that are under the control of NF-kappa-B. Plays a role in the development of endotoxic shock in response to bacterial lipopolysaccharide (LPS) (By similarity). Promotes tubulin polymerization. Promotes phagocyte migration and infiltration of granulocytes at sites of wounding. Plays a role as pro-inflammatory mediator in acute and chronic inflammation and up-regulates the release of IL8 and cell-surface expression of ICAM1. Extracellular calprotectin binds to target cells and promotes apoptosis. Antimicrobial and proapoptotic activity is inhibited by zinc ions 


\section{Table 2 List of the top 10 genes with the greatest increase in expression post infection in milk somatic cells due to} intra-mammary infection with $\mathbf{S}$. aureus (Continued)

\begin{tabular}{|c|c|c|c|}
\hline DNAJB6 & $\begin{array}{l}\text { DnaJ (Hsp40) homolog, subfamily B, } \\
\text { member } 6\end{array}$ & $\begin{array}{l}\text { Plays an indispensable role in the organization of KRT8/KRT18 filaments. } \\
\text { Acts as an endogenous molecular chaperone for neuronal proteins } \\
\text { including huntingtin. Has a stimulatory effect on the ATPase activity of } \\
\text { HSP70 in a dose-dependent and time-dependent manner and hence acts } \\
\text { as a co-chaperone of HSP70. Reduces huntingtin aggregation associated } \\
\text { with HD. Also reduces cellular toxicity and caspase-3 activity }\end{array}$ & 3.2 \\
\hline TNFAIP6 & $\begin{array}{l}\text { tumor necrosis factor, alpha-induced } \\
\text { protein } 6\end{array}$ & $\begin{array}{l}\text { involved in cell-cell and cell-matrix interactions during inflammation and } \\
\text { tumorigenesis }\end{array}$ & 3.1 \\
\hline NCF4 & neutrophil cytosolic factor 4, 40kDa & $\begin{array}{l}\text { Component of the NADPH-oxidase, a multicomponent enzyme system } \\
\text { responsible for the oxidative burst in which electrons are transported } \\
\text { from NADPH to molecular oxygen, generating reactive oxidant } \\
\text { intermediates. It may be important for the assembly and/or activation of } \\
\text { the NADPH-oxidase complex }\end{array}$ & 3.1 \\
\hline STEAP4 & STEAP family member 4 & $\begin{array}{l}\text { Metalloreductase that has the ability to reduce both } \mathrm{Fe}(3+) \text { to } \mathrm{Fe}(2+) \text { and } \\
\mathrm{Cu}(2+) \text { to } \mathrm{Cu}(1+) \text {. Uses } \mathrm{NAD}(+) \text { as acceptor. Play a role in systemic } \\
\text { metabolic homeostasis, integrating inflammatory and metabolic responses } \\
\text { (By similarity). Associated with obesity and insulin-resistance. Involved in } \\
\text { inflammatory arthritis, through the regulation of inflammatory cytokines. } \\
\text { Inhibits anchorage-independent cell proliferation }\end{array}$ & 3.1 \\
\hline
\end{tabular}

reactive oxygen species in macrophages. The remaining 17 genes were distributed as follows: 9 genes (HDAC6, BTK, ARHGEF4, RALA, RALB, FCER1G, LYN, MYL10 and ITGA3) in phospholipase $C$ signalling pathway, 2 genes (IFNGR2 and IRF8) in production of nitric oxide and reactive oxygen species in macrophages, 2 genes (IL1RN and IL1ORB) in IL-10 signalling, 1 gene (TIRAP) in toll like receptor signalling and 3 genes (PTX3, CLEC7A and NOD2) in role of pattern recognition receptors in recognition of bacteria and viruses (Figure 5; Additional file 5).

\section{Gene expression analysis in White Blood Cells (WBC)}

No changes in expression were found between $\mathrm{T} 0$ and T1, T2, T3, T4 for WBC either in the HSCS or LSCS lines, or if the data from both lines were combined. However, analysing the combined data, at T5 9 genes were found to be differentially expressed when compared with T0 ( $\mathrm{p}$ value $<0.05$ and $\log 2$ fold change $>1.5$ ). Eight of these genes showed an increased level of expression and one showed a decrease in expression (Table 5).

\section{Real-time PCR analyses for microarray data validation}

The expression of RPL13A (Ribosomal Protein L13A) showed no significant variation among time points for both milk and blood cells on the array and was therefore used as reference gene for qPCR for both milk and blood samples.

Real-time qPCR was used to confirm the gene expression differences in expression of some genes between $24 \mathrm{~h}$ (T4) and $30 \mathrm{~h}$ (T5) post challenge for milk derived cells and $30 \mathrm{~h}$ (T5) for blood cells.

The gene with the greatest increase in expression from the array data was the PTX3 (Pentraxin 3), which showed a $\operatorname{logFC}$ of 5.6 in the milk derived cells at T4 and a $\log \mathrm{FC}$ of 5.0 in blood cells at T5. The strong increase in gene expression of this gene was confirmed by qPCR with a logFC of 8.6 (T4 vs T0) and 8.9 (T5 vs T0) for milk and 7.2 (T5 vs T0) for blood samples.

Changes in expression observed at $30 \mathrm{~h}$ after challenge (T5 vs T0), from the microarray data were confirmed by qPCR for following genes: S100 calcium-binding protein A8 ( $\log F C 3.0)$, hormone receptor-like 1 (logFC 3.0), hormone receptor-like 1 precursor ( $\operatorname{logFC} 3.3$ ) genes for blood and colony stimulating factor 3 receptor ( $\log$ FC 4.4), Complement C3 precursor (logFC 5.6), IL18 receptor beta (logFC 5.9), leukocyte elastase inhibitor ( $\log F C 3.9)$, myeloid differentiation $(\operatorname{logFC} 3.2)$, pellino protein (logFC 4.3), T-cell activation Rho (logFC 4.4), Thrombomodulin fragment (logFC 3.9 ), Toll-like receptor 4 precursor $(\operatorname{logFC} 5.5)$, tumor necrosis factor (logFC 6.7) genes for milk samples (Additional files 6 and Additional file 7).

\section{Discussion}

This study used a custom microarray to characterise the changes in gene expression during the early response of the goat mammary gland following intra-mammary infection with $S$. aureus. As insufficient caprine sequences were available to create a dedicated goat array, a bovine Combimatrix 90K custom array was used [23]. Technical replicates in preliminary cross species hybridization experiments showed good correlation between replicates confirming the possibility to successfully use this microarray for gene expression analysis in goats. The potential mis-identification of genes using a cross species array was considered to be a potential problem, however, this could be corrected for using specific probes in a subsequent 
Table 3 List of the top 10 genes with an expression decrease in milk somatic cells due to intra-mammary infection with S. aureus

\begin{tabular}{|c|c|c|c|}
\hline $\begin{array}{l}\text { Gene } \\
\text { symbol }\end{array}$ & Gene name & Primary functions & $\begin{array}{l}\text { Log fold } \\
\text { change }\end{array}$ \\
\hline \multicolumn{4}{|l|}{$\overline{\mathrm{T} 4}$} \\
\hline SPP1 & secreted phosphoprotein 1 & $\begin{array}{l}\text { Acts as a cytokine involved in enhancing production of interferon-gamma } \\
\text { and interleukin-12 and reducing production of interleukin-10 and is essential } \\
\text { in the pathway that leads to type I immunity (By similarity) }\end{array}$ & -2.4 \\
\hline$A B C G 2$ & $\begin{array}{l}\text { ATP-binding cassette, sub-family } \\
\text { G (WHITE), member } 2\end{array}$ & $\begin{array}{l}\text { Xenobiotic transporter that may play an important role in the exclusion of } \\
\text { xenobiotics from the brain. May be involved in brain-to-blood efflux. Appears } \\
\text { to play a major role in the multidrug resistance phenotype of several cancer } \\
\text { cell lines. When overexpressed, the transfected cells become resistant to } \\
\text { mitoxantrone, daunorubicin and doxorubicin, display diminished intracellular } \\
\text { accumulation of daunorubicin, and manifest an ATP-dependent increase in } \\
\text { the efflux of rhodamine } 123\end{array}$ & -2.1 \\
\hline CD24 & CD24 molecule & $\begin{array}{l}\text { Modulates B-cell activation responses. Signaling could be triggered by the } \\
\text { binding of a lectin-like ligand to the CD24 carbohydrates, and transduced by } \\
\text { the release of second messengers derived from the GPI-anchor. Promotes } \\
\text { AG-dependent proliferation of B-cells, and prevents their terminal differentiation } \\
\text { into antibody-forming cells }\end{array}$ & -2.0 \\
\hline KRT19 & keratin 19 & $\begin{array}{l}\text { Involved in the organization of myofibers. Together with KRT8, helps to link the } \\
\text { contractile apparatus to dystrophin at the costameres of striated muscle }\end{array}$ & -2.0 \\
\hline EXOSC2 & exosome component 2 & $\begin{array}{l}\text { Component of the exosome } 3^{\prime}->5^{\prime} \text { exoribonuclease complex, a complex that } \\
\text { degrades inherently unstable mRNAs containing AU-rich elements (AREs) within } \\
\text { their } 3^{\prime} \text { untranslated regions. Required for the } 3^{\prime} \text { processing of the } 7 \mathrm{~S} \text { pre-RNA } \\
\text { to the mature } 5.8 \mathrm{~S} \text { rRNA. Has a } 3^{\prime}-5^{\prime} \text { exonuclease activity }\end{array}$ & -1.9 \\
\hline HDAC10 & histone deacetylase 10 & $\begin{array}{l}\text { Responsible for the deacetylation of lysine residues on the N-terminal part of the } \\
\text { core histones }(\mathrm{H} 2 \mathrm{~A}, \mathrm{H} 2 \mathrm{~B}, \mathrm{H} 3 \text { and } \mathrm{H} 4) \text {. Histone deacetylation gives a tag for } \\
\text { epigenetic repression and plays an important role in transcriptional regulation, } \\
\text { cell cycle progression and developmental events. Histone deacetylases act via } \\
\text { the formation of large multiprotein complexes }\end{array}$ & -1.9 \\
\hline C5ORF56 & $\begin{array}{l}\text { chromosome } 5 \text { open reading } \\
\text { frame } 56\end{array}$ & Homo sapiens chromosome 5 open reading frame 56 (C5orf56), mRNA & -1.9 \\
\hline ELF5 & $\begin{array}{l}\text { E74-like factor } 5 \text { (ets domain } \\
\text { transcription factor) }\end{array}$ & $\begin{array}{l}\text { Transcriptionally activator that may play a role in regulating the later stages of } \\
\text { keratinocytes terminal differentiation }\end{array}$ & -1.8 \\
\hline MID2 & midline 2 & $\begin{array}{l}\text { The protein encoded by this gene is a member of the tripartite motif (TRIM) family. } \\
\text { The TRIM motif includes three zinc-binding domains, a RING, a B-box type } 1 \text { and a } \\
\text { B-box type 2, and a coiled-coil region. The protein localizes to microtubular } \\
\text { structures in the cytoplasm. }\end{array}$ & -1.8 \\
\hline REG3G & RNA binding motif protein 5 & $\begin{array}{l}\text { Might be a stress protein involved in the control of bacterial proliferation } \\
\text { (By similarity) }\end{array}$ & -1.8 \\
\hline \multicolumn{4}{|l|}{ T5 } \\
\hline FASN & fatty acid synthase & $\begin{array}{l}\text { Fatty acid synthetase catalyzes the formation of long-chain fatty acids from } \\
\text { acetyl-CoA, malonyl-CoA and NADPH. This multifunctional protein has } 7 \text { catalytic } \\
\text { activities and an acyl carrier protein }\end{array}$ & -2.1 \\
\hline CCNB2 & cyclin B2 & Essential for the control of the cell cycle at the G2/M (mitosis) transition & -1.5 \\
\hline
\end{tabular}

qPRC confirmation step. Thirteen genes with differential expression pre and post infection identified from the microarray analysis were tested by qPCR. In all cases the direction and magnitude of the change in expression seen on the array was confirmed, thus validating the use of the bovine array with goat.

\section{Transcriptome differences between high and low SCC animal groups}

Somatic cell score is strongly correlated with intramammary infection, and mastitis incidence in cattle. Somatic cells score is used in genetic selection with the hope that this will select animal genetically less susceptible to mastitis. Pathogens can only multiply in sufficient quantity to become resident in the gland if the defence mechanisms fail, or are slow to respond to the infection. Therefore, control of invading pathogens within the mammary gland is crucial to prevent the establishment of an infection in the udder, therefore immune cell recruitment is an important part of mammary gland defence against pathogens. Understanding the genetic basis of activation and recruitment of these cells is therefore important to understand the role of these cells in mastitis defence. 
Table 4 Most significant affected IPA canonical pathways

\begin{tabular}{|c|c|c|c|}
\hline Canonical pathway (IPA) & Genes & P-value & Ratio \\
\hline \multicolumn{4}{|l|}{$\mathrm{T4}$} \\
\hline MIF-mediated Glucocorticoid Regulation & TLR4, NFKBIA, CD14, PTGS2, NFKBIB, NFKB1 & 4.67E-06 & $6 / 41$ \\
\hline MIF Regulation of Innate Immunity & TLR4, NFKBIA, CD14, PTGS2, NFKBIB, NFKB1 & $1.8 \mathrm{E}-05$ & $6 / 49$ \\
\hline NF-KB Signalling & $\begin{array}{l}\text { TLR4, IL1A, TGFBR1, RIPK1, NFKBIA, MYD88, BMP2, RELB, TNFAIP3, } \\
\text { NFKBIB, NFKB1 }\end{array}$ & 2.46E-05 & $11 / 176$ \\
\hline IL-10 Signalling & IL18RAP, IL1A, NFKBIA, CD14, ARG2, NFKBIB, NFKB1 & 4.47E-05 & $7 / 78$ \\
\hline Hypoxia Signalling in the Cardiovascular System & $\begin{array}{l}\text { HSP9OB1, UBE2H (includes EG:7328), NFKBIA, UBE2B, HIF1A, } \\
\text { NFKBIB, UBE2L6 }\end{array}$ & $5.4 \mathrm{E}-05$ & $7 / 71$ \\
\hline \multicolumn{4}{|l|}{ T5 } \\
\hline $\begin{array}{l}\text { Production of Nitric Oxide and Reactive Oxygen } \\
\text { Species in Macrophages }\end{array}$ & TLR4, PPP1R3D, NFKBIA, ARG2, NCF4, NFKB1, RHOH, IRF1, SIRPA & $1.98 \mathrm{E}-06$ & $9 / 189$ \\
\hline LXR/RXR Activation & TLR4, IL18RAP, FASN, CD14, ARG2, NFKB1 & $1.85 \mathrm{E}-05$ & $6 / 93$ \\
\hline Toll-like Receptor Signalling & TLR4, NFKBIA, MYD88, CD14, NFKB1 & $2.72 \mathrm{E}-05$ & $5 / 55$ \\
\hline Acute Phase Response Signalling & SOD2, C3, NFKBIA, MYD88, OSM, SERPINA1, NFKB1, SAA1 & 3.59E-05 & $8 / 183$ \\
\hline MIF-mediated Glucocorticoid Regulation & TLR4, NFKBIA, CD14, NFKB1 & 8.09E-05 & $4 / 41$ \\
\hline
\end{tabular}

Five most significant canonical pathways identified with IPA using the significantly affected genes for $T_{4}$ and $T_{5}$. The identified canonical pathways are listed from the lowest to the highest p-value, and are reported with the involved genes and the corresponding ratio (\# of genes involved/ \# of known genes in the pathway).

Goats from two lines selected for high and low SCS were investigated in this study with the hypothesis that the mammary response and function may differ between the lines. A significant difference in macrophage numbers in the udder was observed between the two divergent selection lines prior to infection (T0). As macrophages are the first cellular type involved in the elimination of invading bacteria, the difference may result in dissimilarities between the HSCS and LSCS in early response to natural infection. However, no differences in gene expression in the milk derived cells between the two lines were observed following the experimental challenge carried out in this study. The changes in the numbers and ratios between of cell types are variables dependent on the individual with as much variation seen between compared within line.

Changes expression were also measured in WBC to examine the type and kinetics of systemic in addition to mammary specific responses. Changes in gene expression were observed in the udder from the earliest time point following infection and at 30 hours post infection a large number of genes showed differences. In the

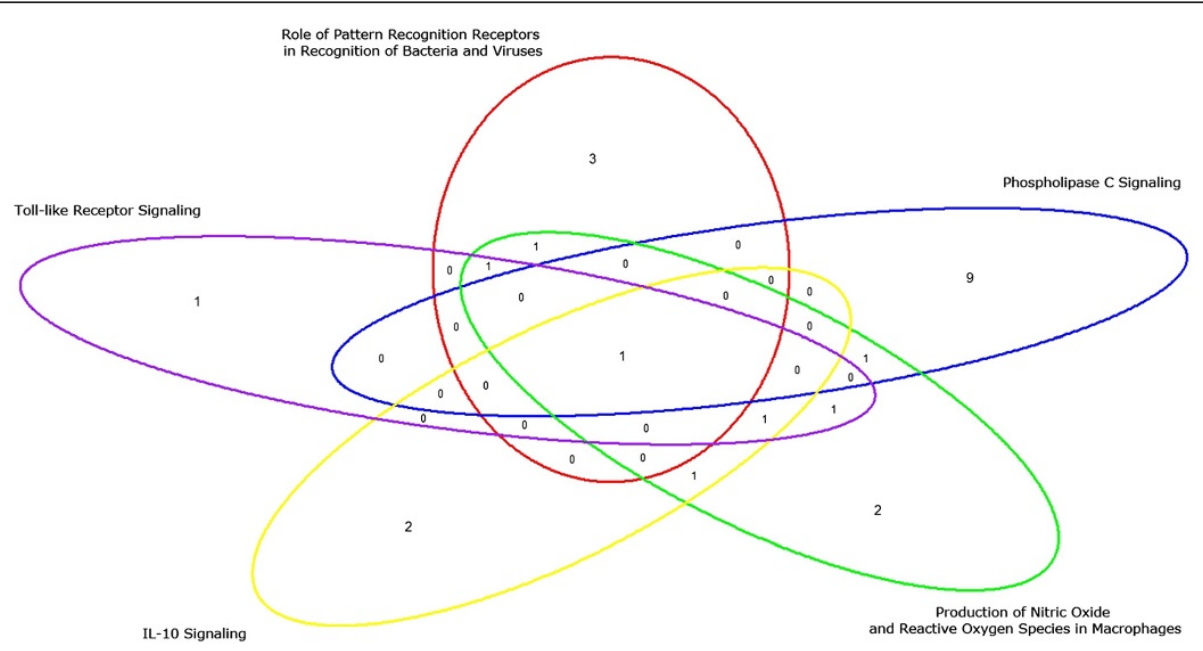

Figure $\mathbf{5}$ Venn diagram of the meta-analysis results. Venn diagram illustrating one gene in common (NFKB1) among the five pathways and distinct genes for the meta-analysis (red: 3 genes of role of pattern recognition receptors in recognition of bacteria and viruses; blue: 9 genes of phospholipase C signalling; green: 2 genes of production of nitric oxide and reactive oxygen species in macrophages; yellow: 2 genes of IL-10 signalling; purple: one gene of toll like receptor signalling). 
Table 5 List of the 9 differentially expressed genes in white blood cells due to intra-mammary infection with S. aureus

\begin{tabular}{|c|c|c|c|}
\hline Gene symbol & Gene name & Gene description & $\begin{array}{l}\text { Log fold } \\
\text { change }\end{array}$ \\
\hline \multicolumn{4}{|l|}{$\mathrm{T}_{5}$} \\
\hline PTX3 & ENSBTAG000000009012 & $\begin{array}{l}\text { Pentraxin-related protein PTX3 precursor } \\
\text { (Pentaxin-related protein PTX3) }\end{array}$ & 4.9 \\
\hline DNAJB6 & gnl|UG|Bt\#S26165666 & $\begin{array}{l}\text { Bos taurus DnaJ (Hsp40) homolog, subfamily B, } \\
\text { member } 6 \text { (DNAJB6), mRNA }\end{array}$ & 2.8 \\
\hline S100A8 & ENSBTAG00000012640 & $\begin{array}{l}\text { Protein S100-A8 (S100 calcium-binding protein A8) } \\
\text { (Calgranulin-A) (Neutrophil cytosolic } 7 \text { kDa protein) } \\
\text { (P7) (BEE11) }\end{array}$ & 2.3 \\
\hline TKDP3 & ENSBTAG00000014345 & Trophoblast Kunitz domain protein 3 (Fragment) & 2.3 \\
\hline EMR1 & ENSBTAG000000007901 & $\begin{array}{l}\text { EGF-like module-containing mucin-like hormone } \\
\text { receptor-like } 1 \text { precursor (Cell surface glycoprotein } \\
\text { EMR1) (EMR1 hormone receptor) }\end{array}$ & 2.3 \\
\hline ACVRIB & gb|CO881044.1|CO881044 & $\begin{array}{l}\text { Homo sapiens activin A receptor, type IB (ACVR1B), } \\
\text { transcript variant } 1 \text {, mRNA }\end{array}$ & 1.7 \\
\hline TGM1 & ENSBTAG000000003920 & transglutaminase 1 & 1.6 \\
\hline CD14 & ENSBTAG00000015032 & $\begin{array}{l}\text { Monocyte differentiation antigen CD14 precursor } \\
\text { (Myeloid cell-specific leucine-rich glycoprotein) }\end{array}$ & 1.5 \\
\hline AMICA1 & ENSBTAG00000023283 & AMICA1 protein & -1.6 \\
\hline
\end{tabular}

blood white cells (WBC) no change in expression was observed at early time points, while at 30 hours post infection only 9 genes were found to be differentially expressed. As may be expected this shows that the systemic response is slower than in the udder following infection with $S$. aureus and that the changes in expression are more restricted, at least in the early phases. This is not surprising as cells in the udder are becoming activated in themselves to respond directly to the invading pathogen or signalling to activate and recruit other cells to the site of infection. This is seen in the gene pathways that are activated and discussed below. Changes occurring in the blood are more suitable, at least at these early stages of infection. Unfortunately samples were not available to investigate how the response progressed later than 30 hours following infection.

\section{Gene expression of milk somatic cells}

The PMN, lymphocytes, macrophages, and epithelial cells in the milk represent important components of the innate immune defence of the mammary gland [10].

These cells release chemokines that stimulate a rapid influx of PMN to combat the bacteria. This response was clearly seen in the present study such that at 24-30h post infection PMN reached over $80 \%$ of cells present, while the percentages of macrophages, lymphocytes and epithelial cells significantly decreased. Differences in cell types composition change the genes products that are detected, irrespective of the actual changes in expression occurring within particular cell types. This makes the interpretation of the data difficult, as the cell population, as well as gene expression within cell types have to be taken into account.

The significant change in macrophage percentages among different time points is related to changes in genes detected that are within canonical macrophages specific pathways such as MIF-mediated Glucocorticoid Regulation, MIF Regulation of Innate Immunity, and Production of Nitric Oxide and Reactive Oxygen Species in Macrophages. The expression of these pathways increased in the context that the macrophage cells percentage decreased, then there is an enormous increase in expression of these genes. Therefore, the microarray data from milk SCC in this study partly reflect changes in gene expression as a result of alteration in cell proportions within the mammary gland, and partly changes in expression within cell types.

At $24 \mathrm{~h}$ following inoculation with S. aureus transcription levels of 300 genes were significantly changed in milk somatic cells. These genes fell into functional pathways which associated with cell death, cellular movement, cellular growth and proliferation, cell-to-cell signalling and interaction, and lipid metabolism.

The levels of the pro-inflammatory cytokines tumour necrosis factor alpha $(T N F \alpha)$, interleukin 1 alpha $(I L-1 \alpha)$, interleukin $8(I L-8)$ were increased in the SCC following challenge. These cytokines are associated with inflammatory processes and are involved in recruitment and activation of neutrophils into the infected tissue [18]. This response following the recognition of invading pathogens, is characteristic of macrophages present among the milk somatic cells, and is instrumental in attracting 
PMN involved in immune defence from the blood to the mammary gland. The response to this signalling is observed in the increased \% of PMN found in the infected gland at 30 hours. Expression of the gene coding for CD14 antigen (CD14), a pivotal cell surface protein on macrophages, that interacts with toll-like receptors mediating detection of bacterial cell wall components, was also increased.

The acute phase response is a rapid and a non-specific inflammatory response that provides the initial line of protection against microorganisms and is regulated through the expression of several cytokines [24]. This is consistent with the early stage response observed in the SCC which involves changes in expression of pathways, including IL-10 Signalling (T4) and LXR/RXR activation (T5). A close relationship between polyamine regulation, in particular the sub-group spermine, and IL-10 Signalling has been previously reported in macrophages [25]. An increase of $I L-6$ and $I L-10$ expression in somatic cells during mastitis infection has also been previously reported in cattle $[18,26]$.

The persistence inflammation, induced by cytokines, is harmful for cells [27] and the affected organ. Therefore the observed activation of the $I L-10$ Signalling, which modulates immune response during the early acute response stage of mastitis infection is important to limit the inflammatory response and tissue damage within the udder. Interleukin-10 is an anti-inflammatory cytokine that blocks NF-kB activity, which leads to suppression of pro-inflammatory mediators such as TNF, IL6, and IL1. Expression was significantly increased for 7 out of 78 putative genes of the $I L-10$ Signalling pathway present on the microarray following infection. Interleukin 1 receptor antagonist (IL1RN) and interleukin 10 receptor beta $(I L 10 R B)$ are also part of the IL-10 Signalling pathway and limit inflammatory response, as well as regulating B-cells, T-cells, NK-cells and dendritic cell division and differentiation, which is associated with the immune response.

Lipid metabolism is generally inhibited during the intra-mammary infections [10]. In the present study the $L X R / R X R$ pathway which is involved in the regulation of lipid metabolism, inflammation, and cholesterol to bile acid catabolism [28] showed reduced expression in SCC following infection. The PPAR family consists of $P P A R \alpha$, $P P A R \delta$, and PPAR , each of which act as ligand activated transcriptional regulators. Expression of these genes was found to be reduced following infection in the present study. The PPAR ligands include $\mathrm{n}-3$ and n-6 unsaturated fatty acids and their eicosanoid products, thus PPARs are involved in the regulation intracellular lipid levels. PPAR is highly expressed in adipose tissue and macrophages and primarily regulates adipogenesis, but also interferes with the transcription of proinflammatory factors such as STAT and NF-kB in macrophages [29]. The down regulation of LXR and RXR and the PPAR genes suggest that during the early stage response to mastitis there might be a "general" deregulation of the lipid metabolism. This has also been observed in cattle infected with $S$. uberis by Moyes et al.[19], where the intra-mammary infection led to the activation of proinflammatory pathways, and a marked inhibition of lipid synthesis. The expression of LXR and PPAR and signalling most likely by PPAR $\gamma$, may provide mechanistic explanation for the inverse relationship between immune response ad fat synthesis. In humans, there is evidence that lipoproteins are part of the innate immune system, and changes in lipid and lipoprotein metabolism that occur during the host response to infection have an anti-infective and anti-inflammatory effect that contributes to the host defence [30].

Moreover, in the stromal vascular fraction, adipose tissue also contains macrophages that secrete proinflammatory cytokines, such as TNF- $\alpha$, IL-1 $\beta$ and IL-6 [31]. Studies focused on the effect of intra-mammary infection in adipose tissue of ruminants are lacking. In a recent work adipose tissue in dairy cows appears to respond in vitro to an immune challenge by increased gene expression of cytokines [32].

Meta-analysis approaches are used to combine or integrate information from independent studies to overcome low statistical power in studies and identify common results to increase confidence in the generality of information [22]. In the present study meta-analysis was used to combine information across samples and timepoints, which identified 17 differentially expressed genes (Figure 5) which are involved in five pathways. Pentraxin 3 (PTX3) was significantly associated with response to infection and increased the expression in both SCC and blood PMN. PTX3 is a C-type lectin domain family 7 member A (CLEC7A) and nucleotide-binding oligomerization domain containing 2 (NOD2) belonged to the Role of Pattern Recognition Receptors in Recognition of Bacteria and Viruses pathway.

The innate immune system uses a several receptors (PRRs) that recognize conserved microbial structures or pathogen-associated molecular patterns (PAMPS), such as those that occur in the bacterial cell-wall components peptidoglycan and lipopolysaccharide. PPRs are classified as: (i) membrane bound PRRs which include toll-like receptors (TLRs), (ii) extracellular PRRs that include the complement proteins, pentraxins and collectins involved in the process of opsonization, phagocytosis and apoptosis and (iii) cytoplasmic PRRs which include the NOD proteins that regulating the cytokine induction initiated by bacterial ligands.

PTX3 is involved in the initial response of mammary tissue to bacterial infection $[18,33,34]$, and is thought to 
activate the immune system by binding both microorganisms and $\mathrm{C} 1 \mathrm{q}$, the first component of the classical pathway of complement activation. NOD2, is expressed in monocytes/macrophages, and detects peptidoglican from gram-negative (for example E. coli) and grampositive bacteria (S. aureus) [35,36]. Although $S$. aureus is usually an extracellular bacterium, it has been shown to be internalised by different mammalian cells such as pulmonary epithelial cells, enterocytes and neutrophils in a manner dependent on the expression of the virulence regulators Agr and SarA [37]. The peptidoglycan fragments from cytoplasm-dwelling bacteria could, therefore, be available for recognition by NOD2 and initiate Nod-dependent cellular responses, making this gene a potential marker for this pathogen infection.

\section{Gene expression white blood cells}

The first changes in gene expression seen in WBC were observed at $30 \mathrm{~h}$ post-infection and coincided with the lowest TBL and NEU counts. At this time point 9 genes were found to be differentially expressed. As for milk somatic cells, in WBC the gene with the highest fold change was PTX3. It was the first long pentraxin identified, an interleukin-1 inducible gene expressed in endothelial cells [38] and is a tumor necrosis factor $\alpha$ $(T N F-\alpha)$ inducible gene in fibroblasts [39]. PTX3 is produced by macrophages and other cell types upon stimulation with primary inflammatory mediators such as LPS, IL-1 or TNF- $\alpha$ [40]. PTX3 plasma levels are very low in normal circumstances $(\leq 2 \mathrm{ng} / \mathrm{ml})$ but expression has been shown to increase following pathogen infection [41]. PTX3 is a functional ancestor of antibodies, recognizing microorganisms, activating complement, and facilitating pathogen recognition by phagocytes. Hence it plays a role in resistance against selected pathogens [42]. Mature PTX3 is stored in specific granules by neutrophils and is secreted following recognition of microbial moieties and inflammatory signals [43]. This protein has been previously identified as one of the most upregulated genes after IMI with $S$. aureus [18]. PTX3 together with $S 100 A 12$ act as anti-microbial agents that could assist defence of the mammary gland against chronic and subclinical infections. In the present study PTX3 was the most significantly up-regulated gene in both somatic cells (T4 and T5) and in WBC (T5) in response to $S$. aureus infection in goats.

\section{Conclusions}

In the present study early response to an experimental challenge with $S$. aureus was studied between two divergent lines of goat selected for high and low milk somatic cell scores. Although the two lines had a pre-infection difference in milk SCC, the gene expression analysis of SCs from the two lines (HSCS vs LSCS) following infection did not show significant differences. The expression analysis showed that expression changes were largely consistent with changes in the cell types in milk, and the activation of immune cell types. An inverse relationship between immune response and lipid metabolism was observed and has previously been described in other species, including cow and sheep.

PTX3 had the higher log fold change in expression in both in milk and in blood and is a candidate for further studies on the genetic basis of variations to in immune response associated with mastitis.

\section{Methods}

Animals

Two groups of five primiparous goats from divergent selection for extreme breeding values for the somatic cell score (one group from the high SCS line and the other from the low SCS line) were selected to have similar milk production $(3.2 \pm 0.5 \mathrm{~kg} / \mathrm{d})$ and provided by INRA. Basically, an experimental genetic evaluation was performed using data from 140,000 primiparous alpine goats in 3625 flock by year combination. The trait considered was the lactation mean of monthly somatic cell scores (LSCS) as detailed in Rupp et al. [12]. Breeding values for LSCS were expressed in genetic standard deviation with inverted sign (positive index are favorable). Two groups of 5 and 6 bucks with extreme high and low breeding values for LSCS $(-1.38 \pm 0.68$ vs $1.17 \pm 0.48$, respectively) were selected to sire daughters at the INRA experimental facility of Bourges (UE0332, OSMOY, France). Out of 52 born kids, two groups of 5 daughters (sired by 3 and 4 high and low SCC bucks, respectively) were transferred two months before first kidding to "Centro Zootecnico Didattico Sperimentale dell'Università degli Studi di Milano-Italy" (http://www.veterinaria.unimi.it/ Facolta/2586_ITA_HTML.html) for experimental infection.

The study was carried out when the goats were of first parity and at the peak of lactation ( $48 \pm 2$ days in milking). Goats were monitored for intra-mammary infections (particularly for $S$. aureus) from parturition to the day of challenge with bacteriological analysis and somatic cell scores measured on milk samples each week as described by Pisoni et al. [21] and Moroni et al. [44]. Fore milk samples were collected on the three days immediately prior to the experimental infection and all animals were shown to be free of any mastitis pathogens and to have SCC below 250,000 cells/mL.

All experimental procedures were performed according to the Italian legislation, following approval by the ethics committee of University of Milan.

\section{Staphylococcus aureus strain}

S. aureus strain DV137, which was originally isolated from chronic case of caprine mastitis [45], was used for 
the experimental infections. S. aureus DV137 is positive for clumping factor, free coagulase, enterotoxins $C$ and L, toxic shock syndrome toxin TSST-1 and leukocidin LukDE.

The S. aureus strain DV137 was grown from an individual colony by transfer to $10 \mathrm{~mL}$ of brain heart infusion broth (Becton-Dickinson Diagnostic Systems, Inc., Milan, Italy) and incubated for $6 \mathrm{~h}$ at $37^{\circ} \mathrm{C}$. Thereafter, 1 $\mathrm{mL}$ of the culture was transferred to $99 \mathrm{~mL}$ of tryptic soy broth (TSB, Difco, Milan, Italy) and incubated overnight at $37^{\circ} \mathrm{C}$. The concentration of the bacterium in this stock culture was maintained at $4^{\circ} \mathrm{C}$ overnight. Before infection the stock was diluted with sterile pyrogenfree Phosphate Buffered Saline (PBS, Invitrogen, Milan, Italy) to give a final concentration of $10^{3}$ Colony Forming Unit/mL (CFU/mL) for the experimental infection.

\section{Intra-mammary challenge}

Prior to intra-mammary challenge the goats were milked by hand and their udders emptied; the teat ends were carefully disinfected with chlorhexidine. The left udder half of each goat was infused with $1 \mathrm{~mL}\left(10^{3} \mathrm{CFU} / \mathrm{mL}\right)$ inoculum of $S$. aureus. The right udder half was infused with $1 \mathrm{~mL}$ of sterile pyrogen-free PBS. Inoculation was administered intra-cisternally through the teat canal using a sterile blunt needle. Milk samples were collected from all goats from both udder halves just prior to the challenge (T0) and at 6 (T1), 12 (T2), 18 (T3), 24 (T4) and 30 (T5) hours after the experimental infection. At each time point each goat was recorded for: general demeanour, stance, position, food/water intake and vocalization, temperature and the udder examined for temperature, swelling, colour, pain, lumps, injuries to the teats/udder, milk letdown, milk colour and milk clots. A paired t-test (with threshold for statistical significance set to 0.05) was applied to body temperature of LSCS and HSCS to test if the differences observed at each time point were significant.

\section{Bacteriology and milk somatic cells analysis}

Twenty ml milk samples were taken under strictly hygienic conditions from each udder half into two sterile $10 \mathrm{ml}$ tubes. One of the tubes was used for bacteriology, while the other tube of milk was used for SCC analysis. Subsequently, $200 \mathrm{~mL}$ of milk were collected from the left infected udders for isolation of cells and further analysis. A paired t-test (with threshold set to 0.05 ) was applied to milk SCC of right udders in LSCS and HSCS goats to test if the changes at each time point were significant.

Milk SCC were determined in 2-mL of milk, which was heated for $15 \mathrm{~min}$ up to $60^{\circ} \mathrm{C}$ then maintained at $40^{\circ} \mathrm{C}$ until analysed, in duplicate, on automated fluorescent microscopic somatic cell counter (Bentley Somacount 150, Bentley Instrument, Milan, Italy). For differential cell counts (DCCs), $10 \mathrm{ml}$ of milk were centrifuged for $15 \mathrm{~min}$ at $400 \times \mathrm{g}$, the cream layer and supernatant were discarded and the cells were washed twice in PBS. DCCs of isolated cell suspensions were estimated by means of esterase stain [46]. Evaluation of the slides was carried out using light microscopy and oil immersion (100-fold magnification). One-hundred cells of each slide were counted meander-shaped and defined as lymphocytes, macrophages, PMN and epithelial cells. Cell identification was achieved using standard methods $[47,48]$.

Aseptically collected milk samples were diluted in sterile PBS and plated onto blood agar plates. The number of CFU was determined after $16 \mathrm{~h}$ of incubation at $37^{\circ} \mathrm{C}$. Colonies displaying haemolysis were initially counted as $S$. aureus, and subsequently confirmed microscopically and biochemically by the presence of Gram-positive cocci that were both catalase- and coagulase-positive. $S$. aureus isolates were tested by RAPD-PCR [49] to confirm that they were the strain used in the experimental challenge.

\section{Blood sample analysis}

Ten ml of blood samples were collected into EDTA from the jugular vein just prior to the challenge and $6,12,18$, 24 , and 30 hours after inoculation.

Blood samples were analyzed using the ADVIA 120 (Siemens Healthcare) haematology system and the multispecies software provided by the manufacturer. The following parameters were calculated: erythrocyte count (RBC), haemoglobin concentration, haematocrit, mean corpuscular volume $(\mathrm{MCV})$, mean corpuscular haemoglobin $(\mathrm{MCH})$, mean corpuscular haemoglobin concentration ( $\mathrm{MCHC})$, leukocyte count (WBC), platelet count (Plt), mean platelet volume (MPV). Leukocyte different counts (percentage and number of neutrophils, lymphocytes, monocytes, eosinophils, basophils and large unstained cells or LUC), were also performed. A paired t-test (with threshold set to 0.05) was applied to blood sample parameters of LSCS and HSCS animals to test if differences at each time point were significant.

\section{Isolation of white blood cells (WBC)}

Ten $\mathrm{ml}$ of fresh blood were transferred into a $50 \mathrm{ml}$ tube and $20 \mathrm{ml}$ of $0.2 \% \mathrm{NaCl}$ were added, mixed with $5 \mathrm{ml}$ of $\mathrm{NaCl} 3.7 \%$ and then centrifuged at $1000 \mathrm{x} \mathrm{g}$ for $10 \mathrm{~min}$ at $4^{\circ} \mathrm{C}$. The pellet was resuspended in $15 \mathrm{ml}$ of PBS and the solution was centrifuged at $1000 \mathrm{xg}$ for $10 \mathrm{~min}$ at $4^{\circ} \mathrm{C}$. The supernatant was discarded and the pellet was resuspended in $1 \mathrm{ml}$ of Trizol (Invitrogen, Milan, Italy).

\section{Preparation of milk somatic cells}

Fore milk was collected aseptically from both halves of the udder of each goat prior to the challenge and 6,12 , 18,24 , and 30 hours post-infection. Fifty $\mathrm{mL}$ of milk were 
transferred to falcon tubes and centrifuged at $750 \times g$ at $4^{\circ} \mathrm{C}$ for $10 \mathrm{~min}$. The fat layer and the supernatant were discarded and the cell pellet was re-suspended and washed in PBS pH 7.2. After a centrifugation at $450 \times \mathrm{g}$ for $10 \mathrm{~min}$, the supernatant was discarded and the pellet was resuspended in $3 \mathrm{~mL}$ of Trizol (Invitrogen, Milan, Italy).

\section{RNA extraction}

From WBC and somatic cells total RNA was extracted following the instructions of the supplier (Invitrogen, Milan, Italy), further purified using an RNeasy MinElute spin column (Qiagen, Milan, Italy) and eluted in RNasefree water. RNA was quantified using a NanoDrop spectrophotometer (NanoDrop Technologies, Wilmington, DE, USA) and quality-checked using a Bioanalyser 2100 (Agilent, Santa Clara, CA). RNA samples with RNA Integrity Number (RIN) values between 7.0 and 10.0 were used for the microarray analysis.

\section{Microrray design}

The microarray design has been described previously [23], briefly all available bovine transcript sequence information was downloaded from Ensembl release 50, and Unigene and dbEST databases (Sept. 2008). A bioinformatic pipeline was created to align the sequences and select a unique set of minimally redundant bovine transcripts. This dataset was used to design 43,768 unique probes with a length of 35 nucleotides, each representing a single bovine transcript. The microarray probes were designed at the $3^{\prime}$ end of the bovine sequences. These probes were synthesised in duplicate, along with negative and quality controls, on a 90K feature custom array from CombiMatrix (Seattle, WA).

\section{Array hybridization and statistical analysis}

One $\mu \mathrm{g} R N A$ was amplified and labelled with Cy5-ULS using the RNA Amplification and Labelling Kit from CombiMatrix (ampULSe Cat. no. GEA-022; Kreatech Biotechnology, Amsterdam, The Netherlands). All procedures were carried out according to the manufacturer's protocols. The purified labelled $a R N A$ was quantified using a NanoDrop spectrophotometer (NanoDrop Technologies, Wilmington, DE, USA). Four $\mu \mathrm{g}$ of labelled $R N A$ were fragmented to a uniform size and hybridized to the custom array following the Combimatrix CustomArray 90K Microarray Hybridization and Imaging Protocol Arrays were stripped and re-hybridised using the CustomArray Stripping Kit for 90K (CombiMatrix Cat. No. 610049) following the protocols of the manufacturer. Each array was used up to 4 times with no deterioration in signal or increase in background.

To verify the powerful of this bovine custom array for the caprine gene expression study, a series of technical replicates were carried out showing a signal intensities correlation higher than $97 \%$ (data not shown).

The hybridised arrays were scanned with a GenePix 4000B microarray scanner (Axon, Toronto, CA) and the images (TIF format) were exported to the CombiMatrix Microarray Imager Software, to perform quality checks of the hybridizations and the spots on the slide. Data were extracted and loaded into the $\mathrm{R}$ software using the Limma analysis package from Bioconductor. A design matrix was created using Limma functions to describe the experimental samples and replicates. The raw intensities were processed using quantile normalization and data were then transformed in $\log 2$ to be used for the statistical analysis.

Limma performs a linear regression analysis on the hybridizations, using a group-means parameterization approach to compare the different conditions and performs a false discovery rate adjustment with BenjaminiHochberg correction for multiple testing [50]. False discovery rates of $1 \%$ and $5 \%$ were accepted for SC and WBC respectively and DE genes were selected using an adjusted P-value cut off equal to 0.01 and 0.05 .

The microarray data files have been deposited in NCBI's Gene expression Omnibus (GEO; http://www.ncbi. nlm.nih.gov/geo/) at the identifier number GPL14856 and the experiment at the identifier number GSE33894.

\section{Assignment of affected genes to pathways, networks and biological functions}

Each gene symbol of the affected genes identified with $\mathrm{R}$ was mapped to its corresponding gene object in the Ingenuity Pathways Knowledge Base. Feeding the lists of affected genes as input to the IPA library identified associated canonical pathways, biological functions and networks which were used to investigate the biological context.

The IPA library items were ranked based on significance of association with the input list of genes. For the canonical pathways this significance was determined based on two parameters: (i) ratio of the number of genes from the input data set that map to the canonical pathway divided by the total number of genes of that pathway and (ii) p-values calculated using Fischer's exact test determining the probability that the association is explained by chance alone.

For the biological functions and networks the significance was linked to the $\mathrm{p}$-value only, calculated by righttailed Fisher's exact test. The p-values for the network analysis take into account the number of affected genes in the network and the size of the network.

\section{Meta-analysis procedures}

Data from all time points were loaded into $\mathrm{R}$ software, the signal intensities were processed and normalized 
using standard Limma procedures, then all the expression data were put together.

MetaMA package was used to perform a moderated t-test with a Benjamini Hochberg $(\mathrm{BH})$ correction at a $0.01 \%$ threshold (to take into account the multiple testing problem) to each time point compared with T0. Once obtained, the p-values from study-specific analysis we combined them into one p-value in sense of sum of logs.

The Venn diagram was built using a modified version of R script "Venn".

http://bioinfo-mite.crb.wsu.edu/Rcode/Venn.R.

\section{Real time PCR validation}

For the optimization of all real-time assays, ten milk RNA samples at T0 were pooled and normalized to a final concentration of $200 \mathrm{ng} / \mu \mathrm{l}$ and the same procedure was used for samples from T4 and T5. RNA from 10 WBC samples at T0 were pooled and normalized to a final concentration of $100 \mathrm{ng} / \mu \mathrm{l}$ and the same procedure was applied to T5 samples. Pooled samples were serial diluted and used for the set-up of the standard curve (5 points in triplicates); in each assay a negative control was also included.

Samples were analysed one by one: $1 \mu \mathrm{g}$ of milk and $0.5 \mu \mathrm{g}$ of blood samples were individually reversetranscribed using the Superscript II RT-PCR System (Invitrogen Life technologies) following the manufacturers instructions. Each sample was tested in triplicates.

Eleven genes from the milk samples and four from blood samples showing high FC and p-values different between post (T4, T5) and pre-infection (T0), were selected for quantitative real-time PCR validation of microarray results.

Caprine specific rtPCR primers were designed using goat sequence where this was available. When goat sequence was not available transcript-specific primers were designed for the conserved regions of the bovine sequence using Primer Express software (version 3.0) running standard settings.

$A C T B$ (actin $\beta$ ), GAPD (glyceraldehyde 3-phosphate dehydrogenase), HMBS (Hydroxymethylbilane synthase), RPL13A (Ribosomal protein L13a), and YWHAZ (Tyrosine 3-monooxygenase/tryptophan 5-monooxygenase activation protein, zeta polypeptide) were selected from literature [51] and tested in order to choose a reference gene common to milk and blood analyses according to the variation in the array data. Control cDNA dilution series were created for each gene to establish a standard curve; all real-time reactions were performed in triplicate.

The real-time reaction mixture, in a final volume of $10 \mu \mathrm{l}$, included $2 \mu \mathrm{l}$ dilution 1:10 of the cDNA as template, $1 \mathrm{X}$ Power SYBR Green Master Mix (Applied Biosystems, Foster City, CA, USA) and $0.5 \mu \mathrm{M}$ of each primer forward and reverse (Additional files 6 and Additional file 7) except for blood-gene egf-like module containing, mucin-like, hormone receptor-like 1 , where final concentration was 0.05 $\mu \mathrm{M}$ for primer forward and $0.9 \mu \mathrm{M}$ for primer reverse. The real-time PCR reaction set up was made in 384 optical well plates with a Freedom Evo Robot (Tecan) and carried out on an ABI 7900HT Fast Real-Time PCR System (Applied Biosystem) with a standard programme $\left(50^{\circ} \mathrm{C}^{*} 2^{\prime} / 95^{\circ} \mathrm{C}^{*} 10^{\prime} /\right.$ 40 cycles $95^{\circ} \mathrm{C}^{*} 15^{\prime \prime}$ and $\left.60^{\circ} \mathrm{C}^{\prime \prime} 1^{\prime}\right)$. Data were analyzed with the GeneAmp 7900HT sequence detection system software (PerkinElmer Corp., Foster City, USA).The log input amount of the standard curve was plotted versus the output $\mathrm{Ct}$ values and the log input amount of each sample was calculated according to the formula $(\mathrm{Ct}-\mathrm{b}) / \mathrm{m}$, where $\mathrm{b}$ is the Y-intercept, and $m$ is the slope. The log input amount was converted to input amount according to the formula $10^{\wedge}$ (log input amount), and triplicate input amounts were averaged for each sample.

Data were imported and processed into $\mathrm{R}$ using the $\mathrm{ddCt}$ analysis package from Bioconductor, time point $\mathrm{T} 0$ and RPL13A were set as reference sample and reference gene respectively and the $2-\Delta \Delta \mathrm{Ct}$ algorithm was applied to find the relative level expression [52].

\section{Additional files}

\section{Additional file 1: Significativity of the differential cell counts analysis calculated for each group of goat (HSCS and LSCS) at different time points. \\ Additional file 2: List of the differentially expressed genes between T4 and T0 in milk samples. Data were extracted and loaded into R software using the Limma analysis package from Bioconductor and the signal intensities were processed and normalized using standard procedures. Genes were considered as differentially expressed if $\mathrm{p}$ value $<0.01$ and $\log 2$ fold change $>1.5$. \\ Additional file 3: List of the differentially expressed genes between T5 and T0 in milk samples. Data were extracted and loaded into R software using the Limma analysis package from Bioconductor and the signal intensities were processed and normalized using standard procedures. Genes were considered as differentially expressed if $p$ value $<0.01$ and $\log 2$ fold change $>1.5$.}

Additional file 4: Most significant affected IPA canonical pathways. The most significant pathways are: MIF-mediated Glucocorticoid Regulation, MIF Regulation of Innate Immunity, NF-kB Signalling, IL-10 Signalling and Hypoxia Signalling in Cardiovascular System for T4 and Production of Nitric Oxide and Reactive Oxygen Species in Macrophages, LXR/RXR Activation, Toll-like Receptor Signalling, Acute Phase Response Signalling and MIF-mediated Glucocorticoid Regulation for T5.

Additional file 5: Role of pattern recognition receptors in recognition of bacteria and viruses pathway. Canonical pathway performed with IPA Knowledge Base.

Additional file 6: Oligonucleotide sequences and results for milk samples q-PCR. The sequences of the couples of primers are listed in the table with q-PCR results.

Additional file 7: Oligonucleotide sequences and results for blood samples q-PCR. The sequences of the couples of primers are listed in the table with $q-P C R$ results.

\section{Abbreviations}

SCS: Somatic Cell Score; SCC: Somatic Cell Count; HSCS: High Somatic Cell Score; LSCS: Low Somatic Cell Score; CFU: Colony Forming Unit; 
RAPD: Random Amplified Polymorphic DNA; MIF: Macrophage Migration Inhibitory Factor; LXR/RXR: Liver X Receptor/Retinoid X Receptors; PPAR: Peroxisome Proliferator-Activated Receptor.

\section{Competing interests}

In the past five years the authors did not receive any reimbursements, fees, funding, or salary from an organization that may in any way gain or lose financially from the publication of this manuscript. The authors did not hold any stocks or shares in an organization that may in any way gain or lose financially from the publication of this manuscript. The authors did not hold or apply for any patents relating to the content of the manuscript and they did not have financial competing interests.

\section{Authors' contributions}

PC and RC prepared RNA for hybridization, performed the microarray experiments, the RT-qPCR analysis and drafted the manuscript. RC, PM1 and GP extracted RNA. GP, PM1 and PM2 performed the challenge, collected samples and carried out the bacteriology and phenotypical analyses. MDC and AS performed all the statistical analyses for microarray and metaanalysis. FS designed the microarray and analysed the raw data. RR selected and provided the animals and HC took care of them at the INRA experimental facility. JLW was involved in array design and participated in writing the paper. BC collaborated in microarray experiments and drafted the paper. AS and RR designed the experiment. AS supervised the experimental study. All authors read and approved the final manuscript.

\section{Acknowledgements}

This work was funded by the EADGENE (EU Contract No. FOOD-CT-2004506416) and SELMOL projects. The authors would like to thank Valerio Bronzo (DIPAV-UNIMI) for the somatic cell type analysis and Caterina Cambuli (ISILS) for the Real Time validation step. The authors highly acknowledge all the staff of the INRA experimental facility at Bourges (UE0332, OSMOY, France) for breeding the goats.

\section{Author details}

'Istituto di Biologia e Biotecnologia Agraria, Consiglio Nazionale delle Ricerche, via Einstein, Lodi 26900, Italy. ${ }^{2}$ IDRA-LAB Istituto Sperimentale Italiano "L. Spallanzani", via Einstein, Lodi 26900, Italy. ${ }^{3}$ Dipartimento di Scienze Veterinarie per la Salute, la Produzione Animale e la Sicurezza Alimentare, Università degli Studi di Milano, via Celoria 10, Milano 20133, Italy. ${ }^{4}$ Parco Tecnologico Padano, via Einstein, Lodi 26900, Italy. ${ }^{5}$ INRA, UR631, Station d'Amélioration Génétique des Animaux, Castanet-Tolosan F-31326, France. ${ }^{6}$ Istituto Zooprofilattico Sperimentale del Piemonte, Liguria e Valle d'Aosta, via Bologna 148, Torino, Italy. ${ }^{7}$ Quality Milk Production Services, Cornell University, 240 Farrier Road, Ithaca, NY 14853, USA.

Received: 5 March 2012 Accepted: 28 September 2012 Published: 9 October 2012

\section{References}

1. Davies G, Genini S, Bishop SC, Giuffra E: An assessment of the opportunities to dissect host genetic variation in resistance to infectious diseases in livestock. Animal 2009, 3:415-436.

2. Sordillo LM: Factors affecting mammary gland immunity and mastitis susceptibility. Livest Prod Sci 2005, 98:89-99.

3. Paape MJ, Mehrzad J, Zhao X, Detilleux J, Burvenich C: Defense of the bovine mammary gland by polymorphonuclear neutrophil leukocytes. J Mammary Gland Biol 2002, 7:109-121.

4. Kehrli ME, Shuster DE: Factors affecting milk somatic-cells and their role in health of the bovine mammary gland. J Dairy Sci 1994, 77:619-627.

5. Paape MJ, Shafer-Weaver K, Capuco AV, Van Oostveldt K, Burvenich C: Immune surveillance of mammary tissue by phagocytic cells. Adv Exp Med Biol 2000, 480:259-277.

6. Riollet $C$, Rainard P, Poutrel B: Cells and cytokines in inflammatory secretions of bovine mammary gland. Adv Exp Med Biol 2000, 480:247-258.

7. Hill AW: Factors influencing the outcome of Escherichia coli mastitis in the dairy cow. Res Vet Sci 1981, 31:107-112

8. Hill AW, Shears AL, Hibbitt KG: The pathogenesis of experimental Escherichia coli mastitis in newly calved dairy cows. Res Vet Sci 1979, 26:97-101.
9. Erskine RJ, Eberhart RJ, Hutchinson LJ, Spencer SB, Campbell MA: Incidence and types of clinical mastitis in dairy herds with high and low somatic cell counts. J Am Vet Med Assoc 1988, 192:761-765.

10. Rinaldi M, Li RW, Capuco AV: Mastitis associated transcriptomic disruptions in cattle. Vet Immunol Immunopathol 2010, 138:267-279.

11. Bonnefont CM, Toufeer M, Caubet C, Foulon E, Tasca C, Aurel MR, Bergonier D, Boullier S, Robert-Granié C, Foucras G, Rupp R: Transcriptomic analysis of milk somatic cells in mastitis resistant and susceptible sheep upon challenge with Staphylococcus epidermidis and Staphylococcus aureus. BMC Genomics 2011, 12:208-224.

12. Rupp R, Clément V, Piacere A, Robert-Granié C, Manfredi E: Genetic parameters for milk somatic cell scores and relationships with production and udder-type traits in dairy Alpine and Saanen primiparous goats. J Dairy Sci 2011, 94:3629-3634.

13. Marogna G, Rolesu S, Lollai S, Tola S, Leori G: Clinical findings in sheep farms affected by recurrent bacterial mastitis. Small Rum Res 2010, 88:119-125.

14. Heringstad B, Klemetsdal G, Ruane J: Selection for mastitis in dairy cattle: a review with focus on the situation of the Nordic countries. Livest Prod Sci 2000, 64:95-106.

15. Rupp R, Foucras G: Genetics of Mastitis in Dairy Ruminants. In Breeding for Disease Resistance in Farm Animals. 3rd edition. Edited by Bishop SC, Axford RFE, Nicholas FW, Owen JB.: CAB International; 2010:183-212.

16. Rupp R, Boichard D, Barbat A, Astruc JM, Lagriffoul G, Barillet F: Selection for mastitis resistance in French dairy sheep. Montpellier, France: In Proceedings of the 7th World Congress on Genetics Applied to Livestock Production; 2002:119-122.

17. Gunther J, Koczan D, Yang W, Nurnberg G, Repsilber D, Schuberth HJ, Park Z, Magbool N, Molenaar A, Seyfert HM: Assessment of the immune capacity of mammary epithelial cells: comparison with mammary tissue after challenge with Escherichia coli. Vet Res 2009, 40:31.

18. Lutzow YC, Donaldson L, Gray CP, Vuocolo T, Pearson RD, Reverter A, Byrne KA, Sheehy PA, Windon R, Tellam RL: Identification of immune genes and proteins involved in the response of bovine mammary tissue to Staphylococcus aureus infection. BMC Vet Res 2008, 4:18.

19. Moyes KM, Drackley JK, Morin DE, Bionaz M, Rodriguez-Zas SL, Everts RE, Lewin HA, Loor JJ: Gene network and pathway analysis of bovine mammary tissue challenged with Streptococcus uberis reveals induction of cell proliferation and inhibition of PPARgamma signaling as potential mechanism for the negative relationships between immune response and lipid metabolism. BMC Genomics 2009, 10:542.

20. Swanson KM, Stelwagen K, Dobson J, Henderson HV, Davis SR, Farr VC, Singh K: Transcriptome profiling of Streptococcus uberis induced mastitis reveals fundamental differences between immune gene expression in the mammary gland and in a primary cell culture model. J Dairy Sci 2009, 92:117-129.

21. Pisoni G, Moroni P, Genini S, Stella A, Boettcher PJ, Cremonesi P, Scaccabarozzi L, Giuffra E, Castiglioni B: Differentially expressed genes associated with Staphylococcus aureus mastitis in dairy goats. Vet Immunol Immunopathol 2010, 135:208-217.

22. Genini S, Badaoui B, Sclep G, Bishop SC, Waddington D, van der Laan MH P, Klopp C, Cabau C, Seyfert HM, Petzl W, Jensen K, Glass EJ, de Greeff A, Smith HE, Smits MA, Olsaker I, Boman GM, Pisoni G, Moroni P, Castiglioni B, Cremonesi P, Del Corvo M, Foulon E, Foucras G, Rupp R, Giuffra E: Strengthening insights into host responses to mastitis infection in ruminants by combining heterogeneous microarray data sources. $B M C$ Genomics 2011, 12:225.

23. Panelli S, Strozzi F, Capoferri R, Barbieri I, Martinelli N, Capucci L, Lombardi G, Williams JL: Analysis of gene expression in white blood cells of cattle orally challenged with bovine amyloidotic spongiform encephalopathy. J Toxicol Environ Health A 2011, 74:96-102.

24. Ramadori G, Christ B: Cytokines and the hepatic acute-phase response. Semin Liver Dis 1999, 19:141-155.

25. Hasko G, Kuhel DG, Marton A, Nemeth ZH, Deitch EA, Szabo C: Spermine differentially regulates the production of interleukin-12 p40 and interleukin-10 and suppresses the release of the Thelper 1 cytokine interferon-gamma. Shock 2000, 14:144-149.

26. Swanson K, Gorodetsky S, Good L, Davis S, Musgrave D, Stelwagen K, Farr V, Molenaar A: Expression of a beta-defensin mRNA, lingual antimicrobial peptide, in bovine mammary epithelial tissue is induced by mastitis. Infect Immun 2004, 72:7311-7314. 
27. Schroder M, Kaufman RJ: The mammalian unfolded protein response. Annu Rev Biochem 2005, 74:739-789.

28. Norata GD, Ongari M, Uboldi P, Pellegatta F, Catapano AL: Liver X receptor and retinoic $X$ receptor agonists modulate the expression of genes involved in lipid metabolism in human endothelial cells. Int $J \mathrm{Mol}$ Med 2005, 16:717-722.

29. Ricote M, Li AC, Willson TM, Kelly CJ, Glass CK: The peroxisome proliferator-activated receptor-gamma is a negative regulator of macrophage activation. Nature 1998, 391(6662):79-82.

30. Khovidhunkit W, Kim MS, Memon RA, Shigenaga JK, Moser AH, Feingold KR, Grunfeld C: Effects of infection and inflammation on lipid and lipoprotein metabolism: mechanisms and consequences to the host. J Lipid Res 2004 , 45(7):1169-1196.

31. Desruisseaux MS, Nagajyothi F, Trujillo ME, Tanowitz HB, Scherer PE: Adipocyte, adipose tissue, and infectious disease. Infect Immun 2007, 75(3):1066-1078

32. Mukesh M, Bionaz M, Graugnard DE, Drackley JK, Loor JJ: Adipose tissue depots of Holstein cows are immune responsive: inflammatory gene expression in vitro. Domest Anim Endocrinol 2010, 38(3):168-178.

33. Bottazzi B, Vouret-Craviari V, Bastone A, De Gioia L, Matteucci C, Peri G, Spreafico F, Pausa M, D’Ettorre C, Gianazza E, Tagliabue A, Salmona M, Tedesco F, Introna M, Mantovani A: Multimer formation and ligand recognition by the long pentraxin PTX3. Similarities and differences with the short pentraxins $C$-reactive protein and serum amyloid $P$ component. J Biol Chem 1997, 272:32817-32823.

34. Garlanda C, Hirsch E, Bozza S, Salustri A, De Acetis M, Nota R, Maccagno A, Riva F, Bottazzi B, Peri G, Doni A, Vago L, Botto M, De Santis R, Carminati P, Siracusa G, Altruda F, Vecchi A, Romani L, Mantovani A: Non-redundant role of the long pentraxin PTX3 in anti-fungal innate immune response. Nature 2002, 420:182-186.

35. Ogura T, Ueda H, Hosohara K, Tsuji R, Nagata Y, Kashiwamura S, Okamura H: Interleukin-18 stimulates hematopoietic cytokine and growth factor formation and augments circulating granulocytes in mice. Blood 2001 98:2101-2107.

36. Girardin SE, Boneca IG, Viala J, Chamaillard M, Labigne A, Thomas G, Philpott DJ, Sansonetti PJ: Nod2 is a general sensor of peptidoglycan through muramyl dipeptide (MDP) detection. J Biol Chem 2003, 278:8869-8872

37. Wesson CA, Liou LE, Todd KM, Bohach GA, Trumble WR, Bayles KW: Staphylococcus aureus Agr and Sar global regulators influence internalization and induction of apoptosis. Infect Immun 1998, 66:5238-5243

38. Breviario F, D'Aniello EM, Golay J, Peri G, Bottazzi B, Bairoch A, Saccone S, Marzella R, Predazzi V, Rocchi M, Della Valle G, Dejana E, Mantovani A, Introna M: Interleukin-1-inducible genes in endothelial cells. Cloning of a new gene related to $C$-reactive protein and serum amyloid $P$ component. J Biol Chem 1992, 267:22190-22197.

39. Lee TH, Wisniewski HG, Vilcek J: A novel secretory tumor necrosis factorinducible protein (TSG-6) is a member of the family of hyaluronate binding proteins, closely related to the adhesion receptor CD44. J Cell Biol 1992, 116:545-557

40. Introna M, Alles W, Castellano M, Picardi G, De Gioia L, Bottazzai B, Peri G, Breviario F, Salmona M, De Gregorio L, Dragani TA, Srinivasan N, Blundell TL, Hamilton TA, Mantovani A: Cloning of mouse ptx3, a new member of the pentraxin gene family expressed at extrahepatic sites. Blood 1996 87:1862-1872

41. Muller B, Peri G, Doni A, Torri V, Landmann R, Bottazzi B, Mantovani A: Circulating levels of the long pentraxin PTX3 correlate with severity of infection in critically ill patients. Crit Care Med 2001, 29:1404-1407.

42. Garlanda C, Bottazzi B, Bastone A, Mantovani A: Pentraxins at the crossroads between innate immunity, inflammation, matrix deposition, and female fertility. Annu Rev Immunol 2005, 23:337-366

43. Jaillon S, Peri G, Delneste Y, Frémaux I, Doni A, Moalli F, Garlanda C, Romani L, Gascan H, Bellocchio S, Bozza S, Cassatella MA, Jeannin P, Mantovani A: The humoral pattern recognition receptor PTX3 is stored in neutrophil granules and localizes in extracellular traps. J Exp Med 2007, 204:793-804

44. Moroni P, Pisoni G, Vimercati C, Rinaldi M, Castiglioni B, Cremonesi P, Boettcher P: Characterization of Staphylococcus aureus isolated from chronically infected dairy goats. J Dairy Sci 2005, 88:3500-3509.
45. Vimercati C, Cremonesi P, Castiglioni B, Pisoni G, Boettcher PJ, Stella A, Vicenzoni G, Moroni P: Molecular typing of Staphylococcus aureus isolated from cows, goats and sheep with intramammary infections on the basis of gene polymorphisms and toxins genes. J Vet Med B Infect Dis Vet Public Health 2006, 53:423-428.

46. Yam LT, Li CY, Crosby WH: Cytochemical identification of monocytes and granulocytes. Am J Clin Pathol 1971, 55:283-289.

47. Coles EH: Leukocytes. In Veterinary Clinical Pathology. 6th edition. Philadelphia PA, USA: WB Saunders Company; 1974:40-98.

48. Lee CS, FBP Wooding P, Kemp P: Identification properties and differential counts of cell populations using electron microscopy of dry cows secretions, colostrum and milk from normal cows. J Dairy Res 1980, 47:39-50.

49. van Leeuwen W, Sijmons M, Sluijs J, Verbrugh H, van Belkum A: On the nature and use of randomly amplified DNA from Staphylococcus aureus. J Clin Microbiol 1996, 34:2770-2777.

50. Smyth GK: Linear models and empirical bayes methods for assessing differential expression in microarray experiments. Stat App/ Genet Mol Biol 2004, 3. Article3.

51. Mane VP, Heuer MA, Hillyer P, Navarro MB, Rabin RL: Systematic method for determining an ideal housekeeping gene for real-time PCR analysis. J Biomol Tech 2008, 19:342-347.

52. Livak KJ, Schmittgen TD: Analysis of relative gene expression data using real-time quantitive PCR and the 2-[delta][delta]CT method. Methods 2001, 25:402-408.

\section{doi:10.1186/1471-2164-13-540}

Cite this article as: Cremonesi et al:: Response of the goat mammary gland to infection with Staphylococcus aureus revealed by gene expression profiling in milk somatic and white blood cells. BMC Genomics 2012 13:540.

\section{Submit your next manuscript to BioMed Central and take full advantage of:}

- Convenient online submission

- Thorough peer review

- No space constraints or color figure charges

- Immediate publication on acceptance

- Inclusion in PubMed, CAS, Scopus and Google Scholar

- Research which is freely available for redistribution 